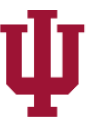

INDIANA UNIVERSITY

PURDUE UNIVERSITY

INDIANAPOLIS

\title{
Developing Organizational Leaders to Manage Publicness: A Conceptual Framework
}

Cullen C. Merritt

Indiana University-Purdue University Indianapolis

Indianapolis, Indiana, USA

Morgan D. Farnworth

Matt R. Kienapple

This is the author's manuscript of the article to be published in final edited form as:

Merritt, Cullen C., Morgan D. Farnworth, Matt R. Kienapple. (Accepted). “Developing Organizational Leaders to Manage Publicness: A Conceptual Framework”. Journal of Public Affairs Education. 


\begin{abstract}
Students enrolled in programs accredited by the Network of Schools of Public Policy, Affairs, and Administration (NASPAA) are increasingly seeking careers outside of classic government organizations. Considering the diversity of job placements with respect to sector (i.e., government, private for-profit, nonprofit), public affairs students may benefit from in-course instruction that aims to develop management competencies that are applicable to any sector. Educating students on publicness theory, specifically managing to achieve public outcomes (i.e., managing publicness), may position these current and future organizational leaders to identify and effectively manage certain structures and institutions in their organization and the external environment. Accordingly, this study provides a conceptual framework in the form of a research-intensive assignment that will equip public affairs students with a working view of how publicness applies to their organizations. By engaging in this research, students acquire practical tools that allow them to consider publicness in their management strategies and decisions regardless of their sector of employment.
\end{abstract}

\title{
INTRODUCTION
}

Public administration scholars generally recognize that government organizations are distinct from private organizations due to a series of factors, such as the degree of political pressure (Wamsley \& Zald, 1973), differences in goods and services provided (Alford, 2002; Rainey, 2014), and commitment to creating public value (Moore, 1995). Such differences often call for distinctive strategies for managing government organizations compared to private organizations (Rainey, 2014). However, the blurring of sectors and the reality that graduates of NASPAAaccredited programs often seek employment in the private and nonprofit sectors calls for public affairs instructors to provide students with management knowledge and skills transferable across 
Developing Organizational Leaders to Manage Publicness: A Conceptual Framework

sectors. In addition, a component of NASPAA's mission centers on "representing to

governments and other institutions the objectives and needs of education for public affairs and administration” (“An Overview of NASPAA”, 2016, italics ours), demonstrating that public affairs education may present implications for government, private, and nonprofit organizations alike. Finally, given that prospective public affairs graduate and undergraduate students may seek employment across sectors (i.e., government, private for-profit, nonprofit) during the course of their lifetimes, public affairs programs have a unique opportunity to elevate recruitment, as this academic field is among the few that develop management competencies at the intersection of all three sectors. According to Bozeman and Moulton (2011),

Public managers often ask some form of this question: "given the organization's mission or objective what are the resources I have available for achieving prescribed public values" (i.e., normative publicness). Empirical publicness directs the public manager to another set of resources: institutional environment and organizational configurations and designs” (Moulton 2009; Shangraw and Crow 1989). A focus on sets of organizations and their environments is less common than is consideration of people, funding, and technology. Perhaps sets of organizations and institutions are less often addressed systematically because the concern straddles public policy and public management. Perhaps the failure to give much attention to analysis of institutions is owing to the fact that highlevel strategic questions are asked all too rarely in public administration (Bryson and Roering 1988). But one limitation to such strategic thinking is a lack of appropriate analytical tools. Possibly,...publicness can help with this respect (i.369).

We agree with Bozeman and Moulton that publicness could be an appropriate analytical tool for strategic thinking about organizational configurations, designs, and external environments as resources for achieving public value. To be sure, we maintain that there are indeed distinctions in managing public versus private organizations (Rainey, 2014). Nevertheless, instructors should consider developing students with management skills applicable to any sector; such skills will position graduates of public affairs programs to shape the realization of the public good in 
Developing Organizational Leaders to Manage Publicness: A Conceptual Framework

various sectoral contexts. Even organizations whose missions are already dedicated to producing public outcomes, defined as goals identified “within policy mandates, legislative intents, [or] public opinion polls” (Moulton, 2009, 89), require competent managers who can adeptly leverage organizational resources, structures, and the external environment. The same can be said for organizations which are not traditionally inclined to pursue public outcomes, such as private firms whose actions reflect Corporate Social Responsibility or "contribute to social welfare, beyond what is required for profit maximization” (McWilliams, 2015, 1).

The objective of this study is to demonstrate the practical benefits of a conceptual assignment on “managing publicness” for current and future organizational leaders. Students enrolled in graduate and undergraduate courses in a public affairs program at a Midwestern, research-intensive university previously executed this assignment, analyzing state and local government, private, and nonprofit organizations, such as: a metropolitan police department, the state police, the State Department of Natural Resources, the State Department of Child Services, the State Department of Transportation, the Boys and Girls Club, Goodwill Industries, the United Way, American Red Cross, Ronald McDonald House, Indianapolis Power \& Light Company, and the American Association for Adult and Continuing Education.

In this paper, we review theories on the distinctiveness of public organizations, publicness, and public value institutions; describe and discuss the Concept Assignment given to graduate and advanced undergraduate students in a public affairs program; and discuss the implications of incorporating publicness research into public affairs coursework.

\section{PUBLICNESS THEORY}


Developing Organizational Leaders to Manage Publicness: A Conceptual Framework

Burgeoning scholarship within public administration research aims to unpack "publicness” (Riccucci, 2010), specifically to identify an organization’s “public” attributes irrespective of sector (Bozeman, 1987; Moulton, 2009). Traditionally, publicness is defined as the extent to which an organization is influenced by political authority, indicated through organizational factors such as government ownership, level of government funding, and degree of exposure to government regulation (Bozeman, 1987; Bozeman and Bretschneider, 1994) In short, the means of classifying an organization's publicness is the degree to which it is subject to governmental influence- - be it imposed through the Constitution, the directives of elected officials and their agents, or other legal mechanisms_-in providing a good or service (Hood, James, and Scott, 2000). However, the blurring of sectors is evidenced by the breadth of providers executing public services, which is not exclusive to government agencies (Moulton, 2009; Moulton, 2010). This reality has motivated scholars to further examine what makes an organization public, and how an organization's publicness may be leveraged to achieve outcomes with implications valuable to the public (Moulton, 2009; Merritt, Cordell, Farnworth, forthcoming).

Distinct methods of identifying an organization's publicness emerge from the public administration literature: the generic (Murray, 1975), core (Rainey, Backoff, Levine, 1976), dimensional (Bozeman, 1987), and realized publicness (Moulton, 2009) frameworks—with each approach building upon and/or challenging insights provided by the preceding theory. Studies in this area often consider the implications of leaders identifying and managing publicness in organizations across sectors (e.g., Andrew, Boyne, Walker, 2011; Antonsen and Jorgensen, 1997; Feeney and Welch, 2012; Johansen and Zhu, 2014). As publicness theory has developed (for summary, see Merritt et al., forthcoming), it has also become increasingly germane to 
Developing Organizational Leaders to Manage Publicness: A Conceptual Framework

educating and developing current and future managers to design their organizations to achieve public outcomes.

\section{The Generic Approach}

The earliest form of sector analysis occurred under the generic approach, where public and private organizations were viewed as not possessing meaningful differences in terms of organizational structures, decision-making processes, or managerial functions (Lau, Newman \& Broedline, 1980; Murray, 1975). Differences identified between the government and private sectors, such as primary objectives and motivations, were also generally discounted, suggesting that sectoral distinctions do not influence the ways in which organizations operate. While opponents of this approach contend that private entities are motivated by economic profits and public organizations by political interests (Rainey et al., 1976), Murray (1975) contends that "the desire for personal power and security is the same; responsiveness to outside pressures is the same. In short, once general priorities are established, public and private bureaucracies operate the same.” (365). Interestingly, motivating the generic approach, in part, are issues at the heart of contemporary dialogue on public-private distinctions: the blurring of sectors (Bozeman, 1987), provision of public goods and services by private entities (Heinrich \& Fournier, 2004; Koppell, 2010 Frederickson, 1999), and the commonality of certain management techniques across public, private, and hybrid organizations (Helco, 1977). However, more recent developments in public administration research reject the generic approach, contending that public organizations maintain distinct goals, structures, processes, and external environments

(Rainey et al., 1976; Rainey, 2014). Such scholarly advancements motivated the development of theory specifically aimed at identifying the distinctive characteristics of government organizations. 
Developing Organizational Leaders to Manage Publicness: A Conceptual Framework

\section{The Core Approach}

The core approach grounds the distinctiveness of public organizations exclusively in legal ownership: either an organization is public and owned by the government, or it is private and owned by a non-governmental entity (Rainey et al., 1976; Bozeman \& Bretschneider, 1994). In light of legal ownership, government and private organizations experience distinctions in internal structures and processes, environmental factors, and transactions between the organization and the environment (Rainey et al., 1976). The ability to classify organizations based upon legal ownership draws a clear line between government and private organizations, allowing for straightforward identification of public organizations and offering strong analytical utility necessary to conduct empirical analysis (Bozeman \& Bretschneider, 1994). Rainey’s (2014) analysis reveals, for example, that "public organizations produce goods and services that are not exchanged in markets” whereas private firms are designed to produce within economic market systems (152). Due in part to sector-specific structures, institutions, and clientele, measures of success are also distinct. Private organizations are primarily judged based on profits and losses, while public organizations are measured by their effectiveness in providing public goods and services (Allison, 1987; Sandfort, 2000). The relatively open interpretation of defining success within public organizations illuminates the difficulty of managing government organizations, thus highlighting the practical importance of distinguishing between government and private organizations via legal ownership.

Empirical limitations of the core approach have been identified, leading scholars to call for a more nuanced means of classifying public organizations (e.g., Bozeman, 1987; Bozeman and Bretschneider, 1994). According to Heinrich \& Fournier (2004), "when organizations do not readily fit into either one of these categories [i.e., public or private]...simple classification 
Developing Organizational Leaders to Manage Publicness: A Conceptual Framework

scheme represents a poor conceptual model and is more likely to produce ambiguous empirical findings” (51, brackets ours). What is more, with the proliferation of private entities providing goods and services that are regarded as public, sectoral affiliation cannot be used as the sole testament to an organization’s publicness (Boyne, 2002; Heinrich \& Fournier, 2004; Moulton, 2009) or potential to produce public value (Bozeman, 2007).

\section{The Dimensional Publicness Approach}

Building on the groundwork laid by the core model, the dimensional publicness approach measures the extent to which an organization is public, instead of classifying organizations as purely public or private (Bozeman, 1987). According to this approach, publicness is captured by the degree to which an organization is subject to political authority, where government ownership, level of government funding, and degree of exposure to government regulation are indicators. Government funding is a source of publicness due to regulatory stipulations often associated with government grants, contracts, and taxation receipts; while funding received through fees paid by consumers and service recipients are more characteristic of private organizations (Andrews, Boyne \& Walker, 2011). Government regulation captures conditions when elected officials and government bureaucrats exert their legal authority to influence organizational policies and practices through laws and oversight (Hood, James \& Scott, 2000).

Stemming from the desire to integrate public policy studies and organizational studies, dimensional publicness observes both political and market-based influences to analyze an organization's publicness, arguably creating a more holistic classification of public organizations (Bozeman, 2013). According to Rainey (2011), scholars most frequently analyze the effects of dimensional publicness on organizational processes and outcomes, such as those associated with: information technology (Bretschneider, 1990), goal ambiguity (Chun and Rainey, 2005), 
Developing Organizational Leaders to Manage Publicness: A Conceptual Framework

strategic management (Bozeman and Straussman, 1990; Nutt and Backoff, 1993), ethical work

climate (Wheeler and Brady, 1998; Wittmer and Coursey, 1996), productivity (Bozeman and

Bretschneider, 1994), quality management (Goldstein and Naor, 2005), and internal resource

acquisition functions (Scott and Falcone, 1998) (see also Bozeman and Moulton, 2011).

\section{Realized Publicness and Public Value Institutions}

The core and dimensional publicness frameworks provide differing perspectives on how to best conceptualize public organizations. However, per Scott \& Falcone (1998), “no one perspective has assumed a level of paradigmatic preeminence,” and one approach may provide increased utility over another, depending on which organizational characteristics are under investigation (4). Similarly, Bozeman and Bretschneider (1994) contend that the two frameworks "are not mutually exclusive alternatives but are instead useful and even complementary alternatives” (218). However, some scholars contend that the core and dimensional approaches measure “governmentalness” instead of publicness (Frederickson, 1997; Koppell, 2010). To bridge the divide between measuring governmentalness and publicness, additional influences on publicness have been explored_-including influences distinct from legal ownership and political authority

(Moulton, 2009; Merritt, 2014). Moulton (2009), referring to her realized publicness framework, comments,

In light of the blurring between sectors, it is critical to not only understand public organizations, but also to identify the factors that contribute to the achievement of public outcomes across sectors...By integrating the theory of dimensional publicness with recent work on public values, this analysis presents a framework that defines realized publicness as public outcomes predicted in part by institutions embodying public values. Based on insights from neo-institutional theory, managing for public outcomes, or managing publicness, requires attention to the combined effects of regulative, associative, and cultural-cognitive public value institutions (889). 
Developing Organizational Leaders to Manage Publicness: A Conceptual Framework

Institutions are defined as "systems composed of regulative, normative, and cognitive cultural elements that act to produce stability and order" (Scott, 2003, 879), including that which is essential to achieve public outcomes (Moulton, 2009). According to Scott (2008), regulative institutions "involve the capacity to establish rules, inspect others" conformity to them, and, as necessary, manipulate sanctions_-rewards and punishment—in an attempt to influence future behavior” (52); normative institutions “introduce a prescriptive, evaluative, and obligatory dimension into social life" (54); cultural cognitive institutions represent "shared conceptions that constitute the nature of social reality and the frames through which meaning is made” (57). Organizational leaders’ abilities to identify and manage regulative, associative, and culture cognitive public value institutions are uniquely positioned to create positive organizational outcomes (Moulton, 2009).

\section{IDENTIFYING AND MANAGING PUBLICNESS: A CONCEPT ASSIGNMENT}

Research on publicness theory increasingly recognizes the practical relevance of publicness for organizational leaders. In particular, Moulton (2009), Bozeman and Moulton (2011), and Merritt et al. (forthcoming) posit that publicness can be managed to specifically achieve public outcomes in organizations regardless of sector. "Managing publicness” requires organizational leaders to not simply understand what makes their organization public, but also requires leaders to understand "what makes [their] organization more likely to provide for public outcomes" (Moulton, 2009, 889, brackets ours).

Graduate and undergraduate students in public affairs academic programs may benefit from considering organizational and environmental structures and institutions most salient in providing for public outcomes. Moulton’s (2009) “Framework for Understanding Components of Publicness” sheds light on management strategies and decisions associated with managing for 
Developing Organizational Leaders to Manage Publicness: A Conceptual Framework

public outcomes in organizational contexts. Moulton (2009) notes that, even though classifying an organization's degree of publicness (or privateness) based on legal ownership or resources/influence from government offers relatively straightforward operationalizations, such indicators "are less informative for policy makers and public managers, particularly those operating across multiple sectors, as they are intended to describe the characteristics that make organization’s public rather than predict potential variation in public outcomes” (890).

Moulton's framework, nonlinear in practice, demonstrates that the realization of public outcomes within organizations is "predicted by the public value institutions that influence organizational strategy” (Moulton, 2009, 891). Under this framework, the process of managing for public outcomes originates with the identification of organizational objectives/goals that align with public values, such as sustainability, social cohesion, or the common good, (see Bozeman, 2007; Crosby and Bryson, 2005 for discussion on public values). Second, these public values are institutionalized within the organization in a range of forms (e.g., activities, processes, practices, structural configurations) including, but not limited to, those associated with government. Public values have the capacity to constrain or empower organizations "when they become institutionalized, either formally (e.g., through regulations) or informally (e.g., through associations or cultures)” (Moulton, 2009, 891). Third, managers must strategize to effectively implement identified policy and management prescriptions specifically related to public value institutions. Each phase of managing publicness - identifying desired public outcomes, identifying public value institutions that may give rise to the identified public outcomes (in addition to or in place of existing organizational strategies), and the execution of strategies related to public value institutions — shape the outputs and public outcomes organizations produce. While this approach to achieving public outcomes is well documented in the literature 
Developing Organizational Leaders to Manage Publicness: A Conceptual Framework

(Bozeman and Moulton, 2011; Moulton, 2009), it is arguably made more accessible to graduate and undergraduate students through their completion of a research-intensive course assignment.

With the objective of developing graduate and undergraduate students through classroom instruction and independent research, a course instructor devised a required paper, titled “Concept Assignment”, for students to gain theoretical insight on publicness and to experience how publicness can be managed within organizations to achieve public outcomes. This course assignment was designed for students, many of whom were mid-career professionals, working in any sector. This assignment was also intended to serve as a conceptual resource for students to use in their professional capacities in the workplace.

Successful completion of the Concept Assignment was made possible through the instructor exposing students to scholarly research, lecturing on publicness, and providing an inclass trial-run of how to identify and manage organizational publicness in a manner consistent with the assignment. Dedicating multiple class sessions to developing student knowledge on publicness prior to their conducting independent research provided additional time for the material to resonate with students and spark independent thinking on the topic. In terms of reading materials, the instructor required students to read Chapter 2 of Hal Rainey’s (2014) text, Understanding and Managing Public Organizations, which offers insight into the generic tradition in organization theory, the blurring of sectors, the purposes of public organizations, and the concept of public values. This chapter is also intended to provide students with an appreciation of government-owned organizations charged with serving the public through a variety of services. The second reading, Chapter 6 of Bozeman's (1987) text, All Organizations are Public: Comparing Public and Private Organizations, demonstrates how organizations in all sectors contain "public" attributes, due to their combination of government ownership, funding, 
Developing Organizational Leaders to Manage Publicness: A Conceptual Framework

and regulation. Beyond providing a framework to classify “public organizations”, Bozeman demonstrates the implications that result from an organization's degree of publicness. Finally, the instructor required Moulton’s (2009) article, “Putting together the publicness puzzle: A framework for realized publicness”, which identifies public value institutions integral to managing for public outcomes, including those not associated with government. The instructor required students to complete these core readings and the supplemental readings noted in Figure 1 prior to the first class session dedicated to publicness. Taken together, these selected readings (an incomplete list, to be sure) provide students with a foundational understanding of how publicness theory has developed and the degree to which this line of research presents implications for organizational managers.

[Figure 1 about here]

Building upon students’ foundational knowledge gained from the readings, the instructor subsequently provided a lecture on publicness, including a discussion on the generic, core, and dimensional publicness frameworks. In doing so, the instructor called attention to how publicness theory is integral to designing and managing organizations to achieve public outcomes. The instructor also noted that while numerous studies consider publicness an input (Bozeman, 1987; Bozeman and Bretschneider, 1994; Rainey et al., 1987), more recent studies identify publicness as an output — the extent to which an organization realizes public outcomes (Moulton, 2009).

Following the class lecture, the instructor distributed the Concept Assignment identified in Figure 2. In addition to explaining the assignment, the instructor conducted a trial-run of the assignment in class (through large group discussion and whiteboard depictions) to provide students with clarity on the assignment's objectives and insight into the types of decisions 
Developing Organizational Leaders to Manage Publicness: A Conceptual Framework

students would make as hypothetical managers. Below, we will discuss how the instructor interactively engaged students on managing publicness prior to their independent completion of the take-home, research assignment. The following reflects the instructions of the Concept Assignment and results of the trial run:

[Figure 2 about here]

A. Select a government, private, or nonprofit organization. Provide a detailed overview of the organization, including: the primary objectives it seeks to achieve, whom it serves (e.g., the general public, a targeted population, etc.), and its value to the public.

For the trail-run of the Concept Assignment, students evaluated the university at which they enrolled in the instructor's courses, given their familiarity with this organization. In a large group discussion, the students identified scholarly research, student education, and providing community services (e.g., fundraising, cleaning up litter) to citizens and organizations in the local community as the university’s primary objectives; the academic/scholarly community (including that which extends beyond the university), students, and state and local stakeholders as the recipients of research, teaching, and service efforts; and conducting and disseminating research as well as academic/educational development as its primary value to the public.

B. Identify the current publicness of this organization by: indicating on three publicness continua (or scales of 1-10, with 10 indicating the highest level of publicness) where this organization is situated with respect to regulative, 
Developing Organizational Leaders to Manage Publicness: A Conceptual Framework

associative, and cultural cognitive dimensions; explaining why you believe this organization is situated at a given point on each continuum/scale.1

Students rated the university’s degree of regulative influence at a 7. Specifically, students noted the university was government owned, which subjected the organization to regulations and oversight regarding state higher education policy, among other forms of regulation. Students also noted that the university received a considerable portion of its funding from state appropriations, which also introduced implications for government regulation and oversight. At the same time, the university was not fully public on the regulative (i.e., political authority) dimension, as funding from student tuition payments and private donations introduced private sources of funding and control. Students rated the university a 7 on the associative dimension. The university fosters a fair amount of horizontal engagement through collaboration with other organizations to achieve desired public outcomes. Partnerships were forged with local nonprofits, the municipal police department, and philanthropic organizations. For example, during numerous campus events, the municipal police department supplemented the university police's efforts in providing public safety for the student and visitor populations. In terms of the cultural cognitive dimension, students ranked the university at a 6, due in large part to its level of engagement with the student population, faculty, alumni, and community stakeholders, mostly to gain insight into how the university could better meet the needs of service delivery clientele,

1 Ratings reflect informed and justified student judgements based on reputable sources of information, and not necessarily advanced quantitative analysis. The goal here is for students to gain a general understanding of the organization's degree of publicness on each dimension through extensive research. 
as well as internal and external stakeholders. For example, cultural cognitive institutions are present in the university’s current strategic planning initiative, where the organization seeks input from a range of stakeholders. The university's Strategic Plan Executive Committee includes members of the campus community (administrators, faculty, staff, and students) and external community that could be directly or indirectly impacted by the university’s actions.

C. If you were the senior manager of this organization, how would you modify (i.e., increase or decrease) your organization's publicness on each dimension to better enable the organization to fulfill its primary objectives identified in Part A? Discuss the specifics of your management strategy.

At this stage, students were charged with specifying how, hypothetically, they would increase, decrease, or better manage the university's existing influence from regulative, associative, and cultural cognitive institutions (with respect to the institutions under managerial/organizational control) to position the university to achieve desired public outcomes identified in Part A (i.e., scholarly research, student education, and providing services to citizens and organizations in the local community). Recognizing that increasing an organization's publicness is not necessarily normative (Bozeman, 1987; Merritt et al., forthcoming), students recommended increasing the university’s level of publicness on each dimension. For the regulative dimension, students recommended that the university aim to increase its level of state appropriations to avoid tuition hikes and to increase federal grant receipts for research purposes from organizations such as the National Science Foundation. Students acknowledged that funding stipulations 
Developing Organizational Leaders to Manage Publicness: A Conceptual Framework

and an increase in government oversight were likely to result from increasing the degree of government funding. Regarding the associative dimension, students recommended the university develop partnerships with globally minded organizations, such as Global Horizons USA, an educational student exchange program. Such partnerships would better enable the university to fulfill its objective regarding student education, specifically positioning students to become exposed, productive citizens more immersed in an increasingly global society. In terms of cultural cognitive institutions, students recommended developing a research task force comprised of community stakeholders. A community-based task force may call on the university to increase their already strong performance in producing research to positively impact the local community. Through this cultural cognitive influence, external community stakeholders (i.e., the general public) would be able to play a more direct role in shaping the future research directions of the university.

Considered collectively, specific strategies emerged from managing the publicness of the university in question. These strategies included: (1) seeking an increase in state appropriations and federal government grants, (2) developing collaborative partnerships with globally minded organizations, and (3) integrating community stakeholder feedback into the research directions of the organization through the creation of a task force. While there are certainly additional strategies essential to meeting the university’s mission and objectives, students’ proposed management strategies suggest that they deem the identified approaches particularly salient in meeting these ends—choosing to leverage higher levels of publicness as opposed to limiting it. 
Developing Organizational Leaders to Manage Publicness: A Conceptual Framework

Students were provided with four weeks to complete the assignment and informed that their papers should go into greater detail than the classroom discussion, particularly in justifying their proposed management strategies (Part C). To successfully complete the Concept Assignment, an extensive amount of research was required. Students were expected to gather or utilize: primary data from an interview with a senior manager of the organization under observation; secondary data, both quantitative and qualitative (e.g., content from the organization’s website); academic articles and books; newspaper articles; and other reputable sources of information. While interviewing one member of senior management was a requirement, students were encouraged to interview additional personnel at varying levels of the organization's hierarchy, such as front-line employees and middle management. This would potentially provide students with a more objective and holistic understanding of their organization. Collectively, these sources of data are intended to provide the researcher with knowledge to articulate, in writing, the organization's primary objectives, clientele, and value to the public (Part A); the current publicness of the organization with respect to regulative, associative, and cultural cognitive dimensions (Part B), and their proposed management strategy regarding the modification of their organization's publicness to better enable the organization to fulfill its primary objectives (Part C).

While we recommend students complete this assignment by analyzing a government or nonprofit organization, the instructor permitted evaluation of a private organization if a student could clearly demonstrate that the private organization in question is committed, at some level, to the achievement of public outcomes (e.g., B Corporations). At the same time, we recommend that instructors inform students that certain organizations (namely for-profit companies) have no obligation to share their internal activities with the public. Therefore, it may be more difficult to 
Developing Organizational Leaders to Manage Publicness: A Conceptual Framework

collect information and conduct research on certain organizations. Exploring a private organization for this research may nonetheless provide a welcome challenge to students interested in entering the private sector after graduation.

This assignment achieves its intended purpose by providing students with an enhanced understanding of how organizations across sectors are comprised with structural mechanisms that may generate public value, the degree to which is often directly dependent on management strategy (Bozeman and Moulton, 2011). Moreover, it provides context for how knowledge on organizational structure and design, management, and public value(s) obtained from public affairs programs is relevant to jobs in the private and nonprofit sectors in addition to classic government organizations.

To build upon the exposure and knowledge students acquire from conducting this research, instructors should consider employing a follow-up assignment or activity to the Concept Assignment. For example, students could compare and contrast strategies associated with managing publicness between two organizations in similar policy domains, but in distinct sectors (e.g., government vs. nonprofit hospital, private vs. nonprofit mental health treatment facility, government law enforcement agency vs. private security firm). In this way, students’ understanding of managing publicness would extend beyond the single sector explored in the research they conducted for the Concept Assignment. This would better prepare students to manage organizations with public goals in mind regardless of the sector in which they pursue careers.

\section{DISCUSSION AND CONCLUSIONS}

In educating current and future organizational leaders, assignments on the topic of publicness, specifically managing for public outcomes, have implications for the management competencies 
Developing Organizational Leaders to Manage Publicness: A Conceptual Framework

students develop. While public management instruction focuses on organizational theory and behavior, which mainly centers on internal mechanisms of the organization, external influences stemming from publicness present additional challenges — and opportunities — to effective management and organizational performance. By harnessing the multiple factors of publicness, practitioners across sectors can help positively steer the direction of organizational behavior (Brewer and Brewer, 2011; Wheeler and Brady, 1998; Wittmer and Coursey, 1996) and performance (Andrews et al., 2011; Johansen and Zhu, 2014; Petrovsky, James \& Boyne, 2015; Walker and Bozeman, 2011).

In analyzing the employment outcomes for graduate and undergraduate students in a public affairs program at a research-intensive university in the Midwest (from which this Concept Assignment is derived), post-graduation job placements may counter expectations. At the Master's level in 2014-15, 38\% of graduates found employment in the private sector, 28\% in the nonprofit sector, and 34\% in the government sector (Indiana University School of Public and Environmental Affairs, 2015). In the 2014-15 undergraduate graduating cohort, 78\% of students found employment at private for-profit organizations, $10 \%$ at private nonprofit organizations, and only $12 \%$ at public organizations (Indiana University School of Public and Environmental Affairs, 2015). Despite this program’s mission of developing future public managers and leaders, graduates of these programs often find employment in the private or nonprofit sectors. In light of students seeking employment across sectors post-graduation, preparing students to become government managers alone may not benefit a large segment of the student population in many public affairs programs. With the primary contribution of this manuscript in mind, it is important for public affairs programs to provide students with management knowledge and skills that are transferable across sectors. 
Developing Organizational Leaders to Manage Publicness: A Conceptual Framework

The task of educating current and future government, private for-profit, and nonprofit managers is one of great importance. According to Moulton (2010), “there has been perhaps no other time in our field’s history when public administration has had greater potential to contribute meaningfully to the future of public aspects of society” (318, italics in original). Organizations across sectors dedicated to improving public outcomes are essential to the functioning of a society; without the application of management and leadership competencies at the intersection of all three sectors (e.g., managing publicness), organizations with public value potential may fail to achieve successful organizational outcomes, sometimes at the expense of the citizenry. As a generational shift takes place with the mass retirement of the baby boomer generation (Getha-Taylor, 2010), the cohort of managers entering organizations must pick up where their predecessors left off. Interestingly, the breadth of organizations contributing to the public good across sectors is more expansive compared to when earlier generations entered the workforce (Crosby and Bryson, 2005). Even more, the rise of globalization, budgeting shortfalls, economic instability, and privatization all signal challenges that must be faced by a range of organizations (Koppell, 2010). Public affairs instruction fostering the development of competencies essential to managing publicness may uniquely prepare future managers for the increasingly complex and ever-changing dynamic of organizations, which are likely to continue moving forward. By educating students to better understand the meaning and implications of publicness and integrating requirements much like the Concept Assignment into course instruction, an additional layer of preparation is given to future managers.

In addition to preparing students to effectively manage organizations, the Concept Assignment calls attention to why publicness is fundamental to students in their roles as private citizens. Even if students lack capacity in their eventual employment to shift their organization's 
Developing Organizational Leaders to Manage Publicness: A Conceptual Framework

focus or investment in the achievement of outcomes that align with public values, they will gain

an appreciation of how activities, such as serving on a community-based task force or

participating in political discourse, can also contribute to the public good.

\section{REFERENCES}

Alford, John. 2002. Defining the client in the public sector: A social-exchange perspective. Public administration review 62:337-346.

Allison, Graham T. 1987. Public and private management: Are they fundamentally alike in all unimportant respects? In Classics of public administration, eds. Jay M. Shafritz and Albert C. Hyde, 510-29. Pacific Grove, CA: Brooks/Cole.

Andrews, Rhys, George A. Boyne, and Richard M. Walker. 2011. Dimensions of publicness and organizational performance: A review of the evidence. Journal of Public Administration Research and Theory 21:i301-i319.

Antonsen, Marianne, and Torben Beck Jørgensen. 1997. The 'publicness' of public organizations. Public Administration 75:337-357.

Boyne, George A. 2002. Public and private management: What's the difference?. Journal of management studies 39:97-122.

Bozeman, Barry. 1987. All organizations are public: Bridging public and private organizational theories. San Francisco: Jossey-Bass.

Bozeman, Barry. 2007. Public values and public interest: Counterbalancing economic individualism. Washington, DC: Georgetown University Press.

Bozeman, Barry. 2013. What organization theorists and public policy researchers can learn from one another: Publicness theory as a case-in-point. Organization Studies 34:169-188.

Bozeman, Barry and Stuart Bretschneider. 1994. The "publicness puzzle” in organization theory: A test of alternative explanations of differences between public and private organizations. Journal of public administration research and theory 4:197-224.

Bozeman, Barry and Stephanie Moulton. 2011. Integrative publicness: A framework for public management strategy and performance. Journal of public administration research and theory 21:i363-i380.

Bozeman, Barry and Jeffrey D. Straussman. 1990. Public management strategies: Guidelines for managerial effectiveness. San Francisco: Jossey-Bass.

Bretschneider, Stuart. 1990. Management information systems in public and private organizations: An empirical test. Public Administration Review 5:536-545.

Brewer, Gene A. and Gene A. Brewer Jr. 2011. Parsing public/private differences in work motivation and performance: An experimental study. Journal of Public Administration Research and Theory 21:i347-i362.

Bryson, John M., Barbara C. Crosby, and Laura Bloomberg. 2014. Public value governance: moving beyond traditional public administration and the new public management. Public Administration Review 74:445-456.

Bryson, J. M., \& Roering, W. D. (1988). Initiation of Strategic Planning by Governments. Public Administration Review, 48(6), 995. doi:10.2307/976996 
Chun, Young Han, and Hal G. Rainey. 2005. Goal ambiguity in US federal agencies. Journal of Public Administration Research and Theory 15:1-30.Crosby, Barbara C., and John M. Bryson. 2005. A leadership framework for cross-sector collaboration. Public Management Review 7:177-201.

Crosby, B. C., \& Bryson, J. M. 2005. Leadership for the common good: Tackling public problems in a shared-power world. John Wiley \& Sons.

Feeney, Mary K., and Eric W. Welch. 2012. Realized publicness at public and private research universities. Public Administration Review 72:272-284.

Frederickson, H. G. (1997). The spirit of public administration. Jossey-Bass Incorporated Pub.

Frederickson, H. G. (1999). The repositioning of American public administration. PS: Political Science \& Politics, 32(04), 701-712.

Getha-Taylor, H. (2010). Human Relations 2.0. Public Administration Review, 70(S1), S170.

Goldstein, Susan Meyer and Michael Naor. 2005. Linking publicness to operations management practices: a study of quality management practices in hospitals. Journal of Operations Management 23:209-228.

Heclo, H. (1977). Political Executives and the Washington Bureaucracy. Political Science Quarterly, 92(3), 395. doi:10.2307/2148500

Heinrich, Carolyn J., and Elizabeth Fournier. 2004. Dimensions of publicness and performance in substance abuse treatment organizations. Journal of Policy Analysis and Management 23:49-70.

Hood, Christopher, Oliver James, and Colin Scott. 2000. Regulation of government: has it increased, is it increasing, should it be diminished?. Public Administration 78:283-304.

Johansen, Morgen and Zhu, Ling, 2014. Market competition, political constraint, and managerial practice in public, nonprofit, and private American hospitals. Journal of Public Administration Research and Theory 24:159-184.

Koppell, J. G. (2010). Administration without Borders. Public Administration Review, 70. doi:10.1111/j.1540-6210.2010.02245.

Lau, A. W., Newman, A. R., \& Broedling, L. A. (1980). The Nature of Managerial Work in the Public Sector. Public Administration Review, 40(5), 513. doi:10.2307/3110205

McWilliams, A. 2015. Corporate Social Responsibility. Wiley Encyclopedia of Management. $12: 1-4$.

Merritt, C.C. (2014). Specifying and Testing a Multi-Dimensional Model of Publicness: A Analysis of Mental Health and Substance Abuse Treatment Facilities (Doctoral dissertation). University of Kansas, Lawrence, KS.

Merritt, C.C., Cordell, K., Farnworth, M.D. (forthcoming). Less is More? Publicness, Management Strategy, and Organizational Performance in Mental Health Treatment Facilities. Public Administration Quarterly.

Moore, M. H. (1995). Creating public value: Strategic management in government. Harvard university press.

Moulton, Stephanie. 2009. Putting together the publicness puzzle: A framework for realized publicness. Public Administration Review 69:889-900.

Moulton, Stephanie. 2010. Integrating the public in public administration: Envisioning the scholarly field in 2020. Public Administration Review 70:s317-s318.

Moulton, Stephanie, and Adam Eckerd. 2012. Preserving the publicness of the nonprofit sector resources, roles, and public values. Nonprofit and Voluntary Sector Quarterly 41:656- 
Developing Organizational Leaders to Manage Publicness: A Conceptual Framework

685.Murray, M. A. (1975). Comparing Public and Private Management: An Exploratory Essay. Public Administration Review, 35(4), 364. doi:10.2307/974538

An Overview of NASPAA. (2016). Retrieved from http://www.naspaa.org/about_naspaa/about/overview.asp

Nabatchi, Tina. 2010. The (re) discovery of the public in public administration. Public Administration Review 70:309-s311.

Nutt, Paul C., and Robert W. Backoff. 1993. Organizational publicness and its implications for strategic management. Journal of Public Administration Research and Theory 3:209-231.

Petrovsky, Nicolai, Oliver James, and George A. Boyne. 2015. New leaders’ managerial background and the performance of public organizations: The theory of publicness fit. Journal of Public Administration Research and Theory 25:217-236.

Rainey, Hal G. 2011. Sampling designs for analyzing publicness: Alternatives and their strengths and weaknesses. Journal of Public Administration Research and Theory 21:i321-i345.

Rainey, H. G. (2014). Understanding and managing public organizations (5th ed.). San Francisco: Jossey-Bass.

Rainey, Hal G., Robert W. Backoff, and Charles H. Levine. 1976. Comparing public and private organizations. Public Administration Review 36:233-244.

Riccucci, Norma M. 2010. Public administration: Traditions of inquiry and philosophies of knowledge. Washington, DC:Georgetown University Press.

Sandfort, Jodi R. 2000. Moving beyond discretion and outcomes: Examining public management from the front lines of the welfare system. Journal of Public Administration Research and Theory 10:729-756.

School of Public and Environmental Affairs. (2015). SPEA Career Development Office 2015 Employment Outcomes Report. Indiana University-Bloomington.

Scott, Patrick G., and Santa Falcone. 1998. Comparing Public and Private Organizations: An Exploratory Analysis of Three Frameworks. The American Review of Public Administration 28:126-145.

Scott, W. Richard. 2003. Institutional Carriers: Reviewing Modes of Transporting Ideas over Time and Space and Considering Their Consequences. Industrial and Corporate Change 12(4): 879-94.

Scott, W. Richard. 2008. Institutions and organizations: Ideas and interests. Thousand Oaks, CA:Sage

Shangraw, R. F., Crow, M. M., \& Overman, E. S. (1989). Public Administration as a Design Science. Public Administration Review, 49(2), 153. doi:10.2307/977335

Walker, Richard M., and Barry Bozeman. 2011. Publicness and organizational performance." Journal of Public Administration Research and Theory 21:i279-i281.

Wamsley, Gary L., and Mayer N. Zald. 1973. The political economy of public organizations: A critique and approach to the study of public administration. Public Administration Review 33:62-73.

Wheeler, Gloria F., and F. Neil Brady. 1998. Do public-sector and private-sector personnel have different ethical dispositions? A study of two sites. Journal of Public Administration Research and Theory 8:93-115.

Wittmer, Dennis, and David Coursey. 1996. Ethical work climates: Comparing top managers in public and private organizations. Journal of Public Administration Research and Theory 6:559-572. 
Figure 1

\section{Required Supplemental Readings}

Allison, Graham T. 1987. Public and private management: Are they fundamentally alike in all unimportant respects? In Classics of public administration, eds. Jay M. Shafritz and Albert C. Hyde, 510-29. Pacific Grove, CA: Brooks/Cole.

Andrews, Rhys, George A. Boyne, and Richard M. Walker. 2011. Dimensions of publicness and organizational performance: A review of the evidence. Journal of Public Administration Research and Theory 21:i301-i319.

Boyne, George A. 2002. Public and private management: what's the difference?. Journal of management studies 39:97-122.

Bozeman, Barry and Stuart Bretschneider. 1994. The "publicness puzzle” in organization theory: A test of alternative explanations of differences between public and private organizations. Journal of public administration research and theory 4:197-224.

Bozeman, Barry and Stephanie Moulton. 2011. Integrative publicness: A framework for public management strategy and performance. Journal of public administration research and theory 21:i363-i380.

Bryson, John M., Barbara C. Crosby, and Laura Bloomberg. 2014. Public value governance: moving beyond traditional public administration and the new public management. Public Administration Review 74:445-456

Feeney, Mary K., and Eric W. Welch. 2012. Realized publicness at public and private research universities. Public Administration Review 72:272-284.

Moulton, Stephanie, and Adam Eckerd. 2012. Preserving the publicness of the nonprofit sector resources, roles, and public values. Nonprofit and Voluntary Sector Quarterly 41:656-685.

Nabatchi, Tina. 2010. The (re) discovery of the public in public administration. Public Administration Review 70:309-s311.

Nutt, Paul C., and Robert W. Backoff. 1993. Organizational publicness and its implications for strategic management. Journal of Public Administration Research and Theory 3:209-231. 
Figure 2

\section{Concept Assignment ${ }^{1}$ \\ Abridged Template}

A. Select a government, private, or nonprofit organization ${ }^{2}$. Provide a detailed overview of the organization, including:

1. The primary objectives it seeks to achieve

2. Whom it serves (e.g., the general public, a targeted population, etc.)

3. Its value to the public

B. Identify the current "publicness" of this organization by:

1. Indicating on three publicness continua (or scales of 1-10, with 10 indicating the highest level of publicness) where this organization is situated with respect to regulative, associative, and cultural cognitive dimensions.

2. Explaining why you believe this organization is situated at a given point on each continuum/scale.

C. If you were the senior manager of this organization, how would you modify (i.e., increase or decrease) your organization's publicness on each dimension to better enable the organization to fulfill its primary objectives identified in Part A? Discuss the specifics of your management strategy.

${ }^{1}$ While you are required to interview one member of senior management, you are encouraged (although not required) to interview additional personnel at varying levels of the organization's hierarchy, such as front-line employees and middle management.

${ }^{2}$ If you evaluate a private organization, you must clearly demonstrate that the organization in question is committed to the achievement of public outcomes at a significant level (e.g., B Corporations). 